An-Nuha: Jurnal Pendidikan Islam

e-ISSN: 2775-7617

p-ISSN: $2775-7226$

http://annuha.ppj.unp.ac.id

Volume 1 Number 4 November 2021, hal. 510-518

\title{
Usaha Ibu Single Parent dalam Mendidik Akhlak Anak
}

\author{
Lastri Fatli Ashari', Fuady Anwar ${ }^{2}$
}

Lastrifatli09@gmail.com ${ }^{1}$, fuadyanwar@fis.unp.ac.id ${ }^{2}$

Universitas Negeri Padang ${ }^{1,2}$

\begin{tabular}{l}
\hline ARTICLE INFO \\
\hline Article history: \\
Received, 21 Oktober 2021 \\
Revised, 10 November \\
2021 \\
Accepted, 30 November \\
2021 \\
\hline
\end{tabular}

\section{Keywords:}

Usaha Ibu, Mendidik

Akhlak, Single Parent

\begin{abstract}
Penelitian ini bertujuan untuk mengetahui permasalahan akhlak anak dalam keluarga single parent. Penelitian ini menggunakan metode kualitatif melalui pendekatan studi kasus. Sumber data penelitian diambil melalui wawancara mendalam kepada 10 (sepuluh) informan yang sudah terpilih dengan menggunakan teknik purposive sampling. Secara keseluruhan hasil penelitian mendapati delapan permasalahan akhak anak. Delapan permasalahan tersebut dikelompokkan kepada dua aspek yaitu 1) tidak patuh terhadap orang tua, 2) permasalahan kepribadian seperti, i) berjudi, ii) berkelahi, iii) mencuri, iv) bergaul bebas, v) terpengaruh game online. vi) cenderung berbohong, vii) pacaran.
\end{abstract}

\section{Clonflict of Interest:}

None

\section{Funding:}

None

Corresponding Author: Lastri Fatli Ashari, Department Islamic Education Faculty of Social Science Universitas Negeri Padang, Indonesia, Email: lastrifatli@gmail.com Phone: +628217306-1126

\section{Pendahuluan}

Orang tua adalah komponen pertama yang bertanggung jawab dalam mendidik. bahkan Imam Al-Ghazali mengatakan bahwa setiap pengetahuan, pengalaman, pendidikan, serta akhlak seorang dipengaruhi oleh lingkungan tempat ia tinggal, oleh karena itu orang tua yang bertanggung jawab mendidiknya, bahkan Allah SWT mengancam dengan ancaman azab yang besar bagi mereka yang meninggalkan, meremehkan atau menghianati amanah yang diberikan Allah AWT (Darajat, 2006). Oleh karena itu orang tua harus bekerja sama dalam mendidik anaknya, sehingga sampai pada tujuan pendidikannya.

Peran orang tua terhadap anak sangatlah penting karena pada era ini kemajuan teknologi semakin meningkat, sehingga ini akan berdampak kepada kehidupan anak. Pada masa ini anak-anak sudah mengenal handphone, televisi, internet, dan peralatan modren lainnya. Oleh karena itu orang tua harus mengawasi anaknya, sehingga dia tidak menonton atau melihat hal-hal negatif lainnya. Karena setiap yang didengar dan dilihat mempengaruhi pola tingkah laku, seperti kebiasaan, tindakan dan sikap anak (Sholeh, 2020).

Pada umumnya penelitian dan isu yang berkaitan mendidik akhlak anak dalam keluarga single parent sudah banyak dikaji sebelumnya. Namun kajian terlebih dahulu hanya berfokus kepada konsep pendidikan akhlak pada keluarga. Minsalnya konsep pendidikan 
akhlak anak (Setiawan, 2017), konsep pendidikan akhlak bagi peserta didik (Hidayat, 2017). Kemudian perspektif lainnya, mengenai pendidikan akhlak pada anak dalam keluarga dapat berupa seperti peran orang tua dalam mendidik akhlak anak (Astuti, 2020), peran orang tua mendidik akhlak anak dalam membentuk keluarga harmonis (Abdulroziq, 2019), strategi pendidikan akhlak anak pada anak (Zamroni, 2017), pendidikan akhlak pada usia dini di era mileneal (Juwita, 2018), peran ibu sebagai orang tua tunggal dalam mendidik akhlak anak (Srinuryanti, 2019).

Beberapa artikel diatas membuktikan bahwa pendidikan akhlak sangat penting dalam kehidupan dan menarik jika dikaji lebih lanjut. Hal itu dikarenakan pentingnya peran orang tua mendidik akhlak anak. Namun setelah penulis analisis dari artikel-artikel tersebut belum ditemukan secara khusus yang membahas tentang bentuk permasalahan anak pada keluarga single parent.

Fakta kurangnya pendidikan akhlak pada anak berdasarkan pengamatan awal penulis pada 20-23 Desember 2020. Berdasarkan pengamatan tersebut terdapat beberapa indikator terkait kurangnya pendidikan akhlak pada anak yaitu pertama; tidak patuh pada orang tua, kedua; sering pulang malam, ketiga; suka membantah perkataan orang tua, keempat; sering bertengkar dengan teman. Semua indikator tentang kurangnya pendidikan akhlak pada anak diatas tentu mempunyai alasan-alasan dan sebab-sebab tertentu. Menurut Sholihin penyebab kurangnya akhlak anak yaitu hubungan keluarga yang tidak harmonis karena orang tua sering cekcok, kondisi ekonomi kurang mencukupi, lingkungan dan pertemanan buruk, dan kurangnya perhatian dari orang tua.

Terkait penyelesaian permasalahan kurangnya pendidikan akhlak pada anak, maka peran orang tua sangat menentukan untuk mendidik kembali akhlak anaknya (Syamsuddin, 2013). Berdasarkan latar belakang masalah sebagaimana yang telah penulis jabarkan di atas maka penulis tertarik untuk mendalami dan meneliti isu ini kedalam sebuah karya ilmiah dengan judul "usaha ibu single parent dalam mendidik akhlak anak di Nagari Air Haji Tenggara.

\section{Tinjauan Pustaka}

\section{Usaha Ibu Single Parent Mendidik Akhlak anak}

Menurut Abdul Nasih Ulwan dalam (Sutinah, 2014) metode yang digunakan dalam menanamkan akhlak kepada anak yaitu sebagai berikut:

1) Metode Keteladanan

Keteladanan merupakan salah satu faktor yang penting dalam keberhasilan Pendidikan. Keteladanan dalam pendidikan salah satu metode yang efektif dan akan mendorong terbentuknya kepribadian anak seperti akhlak, spiritual maupun sosial. Sebab seorang pendidik (ibu) menjadi contoh yang akan ditiru dalam segala prilaku, sopan santun serta semua ucapannya. Secara tidak langsung figur seorang pendidik (ibu) akan tergambar dalam pribadi seorang anak. Ketika pendidik (ibu) jujur, berakhlak mulia, berani dan menjauhkam diri dari perbuatan yang bertentangan dengan agama, maka anak pun akan tumbuh dalam kejujuran, memiliki akhlak yang mulia dan taat beragama.

Sebaliknya ketika figur yang mereka contoh tidak baik, maka anak cenderung untuk mengikuti sifat tersebut. Untuk menerapkan metode teladan dengan baik maka seorang pendidik harus memulai terlebih dahulu untuk diri sendiri seperti membiasakan berakhlak baik setiap hari. Seperti perkataan dan perbuatan yang baik. Kelebihan dari metode ini adalah memberi tahu pengetahuan-pengetahuan yang benar serta mudah dipahami anak.

2) Metode Nasehat

Metode Nasehat adalah suatu metode atau cara seseorang untuk memberi petunjuk kepada yang lain dengan jalan benar serta mengatakan sesuatu sesuai dengan fakta dan disimpaikan dengan cara baik. Nasehat yang diberikan harus berkesan dalam jiwa, sehingga sesuai dengan keimanan serta petunjuk. Oleh karena itu orang tua harus 
memberikan penjelasan yang dapat menyentuh dan menyejukkan hati anak, supaya terjadi perubahan sikap dan perilaku anak.

3) Metode pembiasaan

Metode pembiasaan merupakan metode yang sangat penting dalam pendidikan, karena pembiasan merupakan perilaku yang ditampakkan orang secara otomatis. Seseorang yang mempunyai kebiasaan melakukan pekerjaan dengan cepat maka akan melakukan pekerjaan dengan senang hati, karena sesuatu yang dilakukan sejak kecil akan sulit dirubah setelah dewasa.

4) Metode hukuman

Ibu menanamkannya sebagai lima keharusan yakni menjaga agama, jiwa, kehormatan, akal, dan harta benda. Semua yang disampaikan dalam undang-undang Islam, berupa hukum-hukum prinsip dan syariat semuanya bertujuan untuk menjaga dan memelihara lima keharusan tersebut. Untuk memelihara masalah tersebut syariah telah meletakkan berbagai hukuman yang mencegah, bahkan setiap pelanggaran dan perusak kehormatan akan merasakan kepedihan hukuman-hukuman ini yang dikenal dalam syariat sebagai hudud dan ta'zir. Kelemahan, jika orang tua atau pendidik dalam memberikan hukuman dengan memukul anak maka dapat berakibat buruk pada anak serta bisa melukainya. Memberikan hukuman dengan memukul dada dan perut di larang karena mengakibatkan bahaya besar yang terkadang mengakibatkan kematian.

Pada saat orang tua memberikan hukuman kepada anak dalam keadaan emosi dapat mengakibatkan jiwa anak menjadi stress bahkan menyebabkan trauma. Kelemahan yang lain adalah apabila hukuman yang diberikan tidak efektif, maka akan timbul beberapa kelemahan antara lain: akan membangkitkan suasana rusuh, takut dan kurang percaya diri, anak akan merasa sempit hati, bersifat pemalas, serta akan menyebabkan suka berdusta (karena takut dihukum), mengurangi keberanian anak untuk bertindak.

Kelebihan dengan menggunakan metode ini anak akan merasakan bahwa tujuan pendidik memberikan hukuman bertujuan untuk mendidik dan memperbaiki kekeliruan anak merasa sempit jiwanya, dan menyimpang akhlaknya. Pendekatan hukuman yang dinilai memiliki kelebihan apabila dijalankan dengan benar, yaitu: hukuman akan menjadikan perbaikan-perbaikan terhadap kesalahan pada anak, anak tidak lagi melakukan kesalahan yang sama, merasakan akibat perbuatannya sehingga ia akan menghormati pendidik serta berfikir ulang apabila hendak melakukan kesalahan yang sama

\section{Pengertian dan Tujuan Akhlak}

Secara etimologis pendidikan berasal dari bahasa Yunani kuno, yaitu "pedagogi". Kata dasarnya adalah "paid" yang berarti anak dan "ogogos" yang berarti membimbing. Jadi pedagogi secara harfiah adalah ilmu yang mempelajari tentang seni/cara/metode, mendidik anak didik (Saifuddin, 2016) Sedangkan Menurut Istilah para ahli berbeda pendapat mengenai pendidikan, tergantung kepada objek yang diteliti serta kedalaman ilmunya.

Ahmdi mengatakan Pendidikan adalah suatu proses dan hasil. Sebagai proses pendidikan merupakan kegiatan yang dilakukan manusia dengan lingkungannya. Sedangkan sebagai hasil merupakan kegiatan/interaksi manusia dengan lingkungannya yakni perubahan perilaku (Ahmadi, 2014).

Hal yang sama juga dikatakan oleh Prawironegoro bahwa Pendidikan merupakan suatu proses memberitahu dan mendidik. Memberitahu artinya memasukkan suatu pengertian, pernyataan, dan penalaran ke dalam otak anak sehingga mereka tahu dan paham mengenai sesuatu. Mendidik artinya mengubah perilaku anak yang tidak baik

Dari pendapat di atas dapat dipahami bahwa pendidikan itu merupakan suatu proses pemberian informasi kepada seseorang mengenai suatu hal, dengan metode, 
seni dan cara yang baik, sehingga muncul sebuah reaksi yang sesuai dengan nilai dan norma yang berlaku.

Akhlak ada sesuatu yang harus dimiliki oleh setiap muslim. Akhlak menurut bahasa yaitu jamak dari khuluq yaitu watak, perilaku, atau perbuatan (M. Yatim Abdullah, 2007). Kemudian berdasarkan bahasa Yunani khuluq ini sama dengan ethicos atau ethos, artinya adab, budi pekerti dan tingkah laku, (Mustofa, 1997). Jadi akhlak ini merupakan tingkah laku yang dilakukan secara terus menerus sehingga tercipta sebuah etika (nilai-nilai) yang dilandaskan oleh Al-Qur'an dan sunnah.

Dilihat dari istilah, para ahli berbeda pendapat mengenai akhlak yaitu sebagai berikut:

1) Ibrahim Annis menjelaskan bahwa akhlak adalah ilmu yang membahas tentang perilaku manusia, yang berupa perilaku baik dan buruk (Annis, 1972).

2) Poebakawatja mengatakan bahwa akhlak yaitu suatu tingkah laku, budi pekerti, dan kelakuan baik, yang disebabkan oleh sikap benar tentang Allah dan sesama makhluknya (Poerbakawatja, 1976).

Dari pengertian diatas dapat dipahami bahwa pendidikan akhlak adalah suatu ikhtiar yang dilakukan seseorang untuk mengarahkan anak agar menjadi manusia yang bertanggung jawab, jujur, adil, dan berakhlak karimah yang baik, sehingga berguna bagi nusa dan bangsa.

Tujuan utama pendidikan akhlak yaitu sebagai berikut:

1) Agar terbiasa melakukan hal-hal yang baik dan terhindar dari perilaku buruk.

2) Agar hubungan dengan Allah dan sesama makhluk terjaga dengan baik dan harmonis Barnawy dalam (Zaman, 2018). Sedangkan menurut Hasan dalam (Zaman, 2018) tujuan pokok pendidikan akhlak yaitu: agar semua orang berbudi, berakhlak, bertingkah laku, sesuai dengan ajaran Islam menjadi baik dan sesuai dengan nilai dan norma yang berlaku (Darsono, 2010).

\section{Metode}

Penelitian ini menggunakan metode kualitatif dengan pendekatan studi kasus. Penelitian kualitatif dengan pendekatan studi kasus sangat tepat digunakan dalam penelitian ini karena penulis akan mendeskripkan sebuah fenomena yang belum pernah diungkap sebelumnya (Patton, 1991). Sumber data penelitian diambil kepada sepuluh single parent. Menurut Murniyettti, etc (2016:158) kriteria informan itu terdiri dari empat yaitu: (1) memahami permasalahan penelitian dengan baik, (2) masih aktif dalam bidang penelitian, (3) mempunyai waktu untuk memberikan informasi kepada peneliti, (4) informasi yang diberikan sesuai dengan fakta dilapangan.

Instrument penelitian yang digunakan berupa protokol wawancara terstruktur yang sudah dirancang untuk memandu agar proses wawancara berjalan dengan lancar (Rachmawati, 2007). Data yang dikumpulkan melalui wawancara mendalam dengan menggunakan metode purposive sampling.

\section{Hasil dan Pembahasan}

Data yang disajikan ialah hasil penelitian lapangan dengan menggunakan teknik pengumpulan data observasi, wawancara dan dokumentasi. Berdasarkan hasil wawancara dengan $10 \mathrm{ibu}$ single parent, ditemukan bahwa usaha ibu single parent dalam mendidik akhlak anak yaitu;

\section{a. Permasalahan Akhlak Anak dalam Keluarga Single Parent}

Berdasarkan hasil wawancara dengan seluruh informan, secara umum didapati dua tema penting permasalahan akhlak anak dalam keluarga single parent. Dua permasalahan yang dimaksud adalah i) tidak patuh pada orang tua, ii) permasalahan kepribadian anak. Agar lebih jelas dua tema diatas disampaikan oleh informan dalam bentuk bahasa yang berbeda, namun maksud dan tujuan sama. Berikut ini penulis deskripsikan hasil wawancara tersebut sesuai dengan tema yang sedang dibicarakan. 
Lastri Fatli Ashari dan Fuady Anwar: Usaha Ibu Single Parent dalam Mendidik Akhlak...

Tabel. 1: kutipan Wawancara Tidak Patuh pada Orang Tua

\begin{tabular}{|c|c|c|}
\hline Tema & Informan & Petikan Wawancara \\
\hline \multirow[t]{4}{*}{$\begin{array}{l}\text { Tidak patuh } \\
\text { pada orang } \\
\text { tua }\end{array}$} & $\begin{array}{l}\text { Single } \\
\text { parent } 1\end{array}$ & $\begin{array}{l}\text {...,bentuk tidak patuh anak pada orang tua yaitu tidak } \\
\text { mendengarkan nasehat yang diberikan oleh orang } \\
\text { tua,.... }\end{array}$ \\
\hline & $\begin{array}{c}\text { Single } \\
\text { parent } 3\end{array}$ & $\begin{array}{l}\text {....,mengabaikan perintah orang tua, seperti anak terus } \\
\text { bermain game online meski sudah diminta orang tua } \\
\text { untuk berhenti,.... }\end{array}$ \\
\hline & $\begin{array}{c}\text { Single } \\
\text { parent } 7\end{array}$ & $\begin{array}{l}\text {..., menolak panggilan dari orang tua dan sibuk dengan } \\
\text { dunianya,... }\end{array}$ \\
\hline & $\begin{array}{l}\text { Single } \\
\text { parent } 10\end{array}$ & $\begin{array}{l}\text {...,menunda-nunda memenuhi permintaan orang tua } \\
\text { dan anak sibuk dengan aktivitasnya,... }\end{array}$ \\
\hline
\end{tabular}

Tabel. 2: Kutipan Wawancara Permasalahan Kepribadian

\begin{tabular}{|c|c|c|}
\hline Tema & $\begin{array}{l}\text { Informa } \\
\mathrm{n}\end{array}$ & Petikan Wawancara \\
\hline $\begin{array}{l}\text { Permasalaha } \\
\text { n }\end{array}$ & $\begin{array}{l}\text { Single } \\
\text { parent } 8\end{array}$ & $\begin{array}{l}\text {....,Bentuk permasalahan yang dilakukan anak saya } \\
\text { berkelahi dengan teman disekolah,.... }\end{array}$ \\
\hline \multirow[t]{5}{*}{ kepribadian } & $\begin{array}{l}\text { Single } \\
\text { parent } 1\end{array}$ & ...,Cendrung berjudi dan mencuri ,.... \\
\hline & $\begin{array}{l}\text { Single } \\
\text { parent } 6\end{array}$ & $\begin{array}{l}\text {....,karena kesibukan saya bekerja anak kurang } \\
\text { perhatian sehingga salah pergaulan,... }\end{array}$ \\
\hline & $\begin{array}{l}\text { Single } \\
\text { parent } 3\end{array}$ & $\begin{array}{l}\text {....,Penyebab anak saya malas adalah terpengaruh } \\
\text { dari game online,.... }\end{array}$ \\
\hline & $\begin{array}{l}\text { Single } \\
\text { parent } 1\end{array}$ & $\begin{array}{l}\text {....,Anak saya cendrung berbohong karena takut } \\
\text { pada ibu,... }\end{array}$ \\
\hline & $\begin{array}{l}\text { single } \\
\text { parent }\end{array}$ & $\begin{array}{l}\text {....,Anak saya izinkan berpacaran, sehingga anak } \\
\text { tidak merasa terkekang,... }\end{array}$ \\
\hline
\end{tabular}

Akhlak adalah sesuatu yang harus dimiliki oleh setiap muslim. Akhlak menurut bahasa yaitu jamak dari khuluq yaitu watak, perilaku, atau perbuatan (M. Yatim Abdullah, 2007). Kemudian berdasarkan bahasa Yunani khuluq ini sama dengan ethicos atau ethos, artinya adab, budi pekerti dan tingkah laku, (Mustofa, 1997). Jadi akhlak ini merupakan tingkah laku yang dilakukan secara terus menerus sehingga terciptalah sebuah etika (nilai-nilai) yang dilandaskan oleh Al-qur'an dan sunnah. Dilihat dari istilah, para ahli berbeda pendapat mengenai akhlak yaitu sebagai berikut:

1) Ibrahim Annis menjelaskan bahwa akhlak adalah ilmu yang membahas tentang perilaku manusia, yang berupa perilaku baik dan buruk (Annis, 1972).

2) Poebakawatja mengatakan bahwa akhlak yaitu suatu tingkah laku, budi pekerti, dan kelakuan baik, yang disebabkan oleh sikap benar tentang Allah dan sesama makhluknya (Poerbakawatja, 1976).

3) Yaqub mendefiniskan akhlak yaitu sebagai berikut:

(a) Akhlak adalah ilmu yang menentukan batas antara baik dan buruk, terpuji dan tercela, tentang suatu perkataan atau perbuatan manusia baik lahir maupun batin.

(b) Akhlak merupakan ilmu pengetahuan yang memberikan penjelasan baik dan buruk, serta ilmu yang mengajarkan pergaulan manusia dan menyatakan tujuan mereka yang terakhir dari seluruh manusia dan pekerjaan mereka (Ya'qub, 1993). 
Dari pengertian diatas dapat dipahami bahwa pendidikan akhlak adalah suatu ikhtiar yang dilakukan seseorang untuk mengarahkan peserta didik agar menjadi manusia yang bertanggung jawab, jujur, adil, dan berakhlak karimah yang baik, sehingga berguna bagi nusa dan bangsa. Dari pengertian diatas dapat dipahami bahwa pendidikan akhlak adalah suatu ikhtiar yang dilakukan seseorang untuk mengarahkan peserta didik agar menjadi manusia yang bertanggung jawab, jujur, adil, dan berakhlak karimah yang baik, sehingga berguna bagi nusa dan bangsa. Kemudian akhlak sangat penting dididik secara berkelanjutan, karena dalam siklus ini masa kanak-kanak adalah masa yang sangat penting untuk membangun karakter anak (Haq, 2015). Hal ini sesuai dengan firman Allah dalam ayat Al-Qur'an pendidikan ini terdapat pada Q.S. At-Tahrim ayat 6:

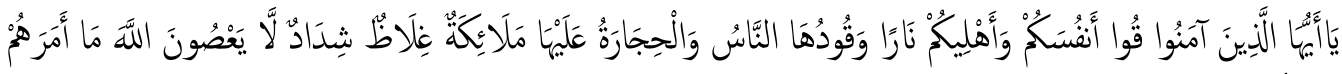

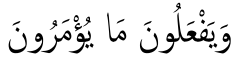

Artinya: Hai orang-orang yang beriman, peliharalah dirimu dan keluargamu dari api neraka yang bahan bakarnya adalah manusia dan batu, penjaganya malaikat-malaikat yang kasar, keras, dan tidak mendurhakai Allah terhadap apa yang diperintahkan-Nya kepada mereka dan selalu mengerjakan apa yang diperintahkan.

Orang tua adalah komponen pertama yang bertanggung jawab dalam mendidik. bahkan Imam Al-Ghazali mengatakan bahwa setiap pengetahuan, pengalaman, pendidikan, serta akhlak seorang dipengaruhi oleh lingkungan tempat ia tinggal, oleh karena itu orang tua yang bertanggung jawab mendidiknya, bahkan Allah swt mengancam dengan ancaman azab yang besar bagi mereka yang meninggalkan, meremehkan atau menghianati amanah yang diberikan Allah SWT (Darajat, 2006). Oleh karena itu orang tua harus bekerja sama dalam mendidik anaknya, sehingga sampai pada tujuan pendidikannya. Namun dalam kenyataannya banyak dari orang tua hanya menyerahkan pendidikan anaknya ke lingkungan atau sekolah, sehingga ini berdampak buruk pada akhlak anak. Seperti anak tidak patuh pada orang tua, menunda-nunda permintaan orang tua, berkelahi, dan berjudi,

\section{b. Usaha Ibu Mendidik Akhlak Anak dalam Keluarga Single Parent}

Berdasarkan hasil wawancara dengan informan terdapat lima tema penting usaha yang dilakukan single parent dalam mendidik akhlak anak. lima usaha yang dimaksud adalah i) mendidik akhlak sejak dini, ii) memantau ibadah anak, iii) menjadi teladan bagi anak, iv) memberikan nasehat dan hukuman untuk anak, v) dan memantau pergaulan anak.

Lima usaha yang dilakukan ibu dalam mendidik akhlak anak didapat dari informan ketika wawancara langsung dilakukan. Informasi tersebut disampaikan oleh informan dalam bahasa yang sedikit berbeda, namun tujuan kurnag lebih sama. Berikut ini penulis akan deskripsikan hasil wawancara tersebut sesuai dengan tema yang sedang dibincangkan.

Tabel 3: Kutipan Wawancara Usaha Ibu Mendidik Akhlak Anak (Mendidik Akhlak Sejak Dini)

\begin{tabular}{|c|c|c|}
\hline Tema & Informan & Petikan Wawancara \\
\hline \multirow[t]{4}{*}{$\begin{array}{l}\text { Mendidik } \\
\text { akhlak } \\
\text { sejak dini }\end{array}$} & $\begin{array}{c}\text { Single } \\
\text { parent } 1\end{array}$ & $\begin{array}{l}\text { Salah satu cara yang dapat dilakukan orang tua } \\
\text { dalam mendidik akhlak anak dengan membiasakan } \\
\text { berdo'a sebelum makan. }\end{array}$ \\
\hline & $\begin{array}{c}\text { Single } \\
\text { parent } 3\end{array}$ & $\begin{array}{l}\text { Cara yang dilakukan dalam mendidik akhlak anak } \\
\text { adalah mengajarkan sopan santun kepada anak. }\end{array}$ \\
\hline & $\begin{array}{l}\text { Single } \\
\text { parent } 6\end{array}$ & $\begin{array}{l}\text {...,cara lain yang saya lakukan dalam mendidik } \\
\text { akhlak anak adalah mengajarkan do'a sebelum tidur }\end{array}$ \\
\hline & $\begin{array}{c}\text { Single } \\
\text { parent } 8\end{array}$ & $\begin{array}{l}\text { Ini penting dilaksanakan sehingga tertanam akhlak } \\
\text { baik seperti jujur, tolong menolong, dan sopan } \\
\text { santun. }\end{array}$ \\
\hline
\end{tabular}


Lastri Fatli Ashari dan Fuady Anwar: Usaha Ibu Single Parent dalam Mendidik Akhlak...

Tabel 4: Kutipan Wawancara Usaha Ibu Mendidik Akhlak Anak

(Menasehati Anak)

\begin{tabular}{|c|c|c|}
\hline Tema & Informan & Petikan Wawancara \\
\hline \multirow[t]{4}{*}{$\begin{array}{l}\text { Menasehati } \\
\text { anak }\end{array}$} & $\begin{array}{l}\text { Single } \\
\text { parent } 1\end{array}$ & $\begin{array}{l}\text { Selain mendidik akhlak sejak dini, saya juga } \\
\text { menasehati anak jika dia berbuat salah. Minsalkan } \\
\text { jangan bertengkar dengan teman. }\end{array}$ \\
\hline & $\begin{array}{l}\text { Single } \\
\text { parent } 4\end{array}$ & $\begin{array}{l}\text { Menasehati anak agar sebelum masuk rumah } \\
\text { membaca salam }\end{array}$ \\
\hline & $\begin{array}{c}\text { Single } \\
\text { parent } 7\end{array}$ & $\begin{array}{l}\text { Akhlak yang baik sangat berguna bagi kehidupan } \\
\text { dunia oleh karena itu, jika anak saya buat masalah } \\
\text { maka saya menasehati dia secara kontinyu. }\end{array}$ \\
\hline & $\begin{array}{c}\text { Single } \\
\text { parent } 5\end{array}$ & $\begin{array}{l}\text { Cara saya mendidik anak agar dia berubah untuk } \\
\text { meninggalkan pergaulan bebas yaitu memberikan } \\
\text { nasehat kepada anak serta mintak tolong ke orang } \\
\text { terdekat untuk menasehatinya. }\end{array}$ \\
\hline
\end{tabular}

Tabel 5: Kutipan Wawancara Usaha Ibu Mendidik Akhlak Anak (Memberi Hukuman)

\begin{tabular}{|c|c|c|}
\hline Tema & Informan & Petikan Wawancara \\
\hline \multirow[t]{5}{*}{$\begin{array}{l}\text { Memberi } \\
\text { hukuman }\end{array}$} & $\begin{array}{c}\text { Single } \\
\text { parent } 5\end{array}$ & $\begin{array}{l}\text { Supaya anak tidak melakukan kesalahan yang } \\
\text { sama seperti melawan, hukuman yang saya beri } \\
\text { adalah mencubitnya. }\end{array}$ \\
\hline & $\begin{array}{c}\text { Single } \\
\text { parent } 4\end{array}$ & $\begin{array}{l}\text { Agar pencurian, berjudi anak berubah saya } \\
\text { hukuman dia dengan tidak memberi uang } \\
\text { jajannya. }\end{array}$ \\
\hline & $\begin{array}{c}\text { Single } \\
\text { parent } 9\end{array}$ & $\begin{array}{l}\text { Anak yang main game online secara terus } \\
\text { menerus akan berdampak negative kepada anak, } \\
\text { agar anak tidak candu lagi, maka hpnya akan saya } \\
\text { ambil selama 1minggu }\end{array}$ \\
\hline & $\begin{array}{c}\text { Single } \\
\text { parent } 7\end{array}$ & $\begin{array}{l}\text { Awalnya anak saya ini suka bertengkar dengan } \\
\text { adiknya, setelah saya pukul keduanya. Anak ini } \\
\text { tidak bertengkar lagi. }\end{array}$ \\
\hline & $\begin{array}{c}\text { Single } \\
\text { parent } 10\end{array}$ & $\begin{array}{l}\text { Hal yang saya lakukan agar hal yang serupa tidak } \\
\text { terulang minsalnya berbohong, melawan ortu, } \\
\text { yaitu memukul anak dengan kayu. Namun itu } \\
\text { hanya saya lakukan ketika kesal dengan anak. }\end{array}$ \\
\hline
\end{tabular}

Tabel 6: Kutipan Wawancara Usaha Ibu Mendidik Akhlak Anak (Menjadi Teladan)

\begin{tabular}{c|c|l}
$\begin{array}{c}\text { Tema } \\
\text { Menjadi } \\
\text { teladan }\end{array}$ & $\begin{array}{c}\text { Snforman } \\
\text { parent } 9\end{array}$ & $\begin{array}{l}\text { Sebenarnya banyak cara mendidik anak namun } \\
\text { yang paling utama adalah memberikan teladan } \\
\text { yang baik kepada anak. Minsalnya sebelum saya } \\
\text { menyuruh anak untuk sholat, maka saya yang } \\
\text { sholat terlebih dahulu. }\end{array}$ \\
\hline $\begin{array}{c}\text { Single } \\
\text { parent } 8\end{array}$ & $\begin{array}{l}\text { Keluarga adalah tempat pendidikan yang pertama } \\
\text { dan utama bagi anak. Oleh karena itu saya } \\
\text { berusaha mendidik anak dengan menjadi figur } \\
\text { yang baik bagi anak. }\end{array}$ \\
\end{tabular}


Berdasarkan hasil wawancara diatas dapat disimpulkan bahwa secara umum usaha yang dilakukan orang tua dikelompokkan menjadi tiga yaitu: i) nasehat, ii) keteladanan, iii) hukuman. Lebih jelasnya akan penulis paparkan di bawah ini:

1) Nasehat

Metode Nasehat adalah suatu metode atau cara seseorang untuk memberi petunjuk kepada yang lain dengan jalan benar dan mengatakan sesuatu yang benar untuk melunakkan hati orang lain. Nasehat harus berkesan dalam jiwa atau mengikat jiwa dengan keimanan dan petunjuk. Sehingga orang tua harus memberikan penjelasan yang dapat menyentuh dan menyejukkan hati anak, supaya terjadi perubahan sikap dan perilaku menuju kepada hal-hal atau amalan kebaikan bagi kehidupan pribadi, keluarga maupun masyarakat (Sutinah, 2014). Bentuk nasehat yang diberikan orang tua kepada anak adalah dengan menasehati anak di saat buat salah. Hal ini dilakukan orang tua agar anaknya tidak melakukan hal yang sama ke depannya.

2) Keteladanan

Metode keteladanan adalah diambil dari kata uswatun hasanah. Uswatun hasanah adalah contoh yang baik, suri teladan yang baik. Jadi metode keteladanan adalah pendidikan dengan memberi contoh yang baik. Seperti perkataan yang baik, perbuatan maupun cara berfikir yang baik. Kelebihan dari metode ini adalah mengajarkan pengetahuan-pengetahuan yang bersifat praktis serta mudah dipahami anak (Sutinah, 2014). Bentuk keteladanan yang diberikan orang tua kepada anak yaitu dengan memberikan contoh yang baik kepada anak seperti sholat tepat waktu, dan disiplin terhadap waktu.

3) Hukuman

Metode hukuman dilakukan orang tua agar kesalahan yang sama tidak terulang. Bentuk hukuman yang diberikan orang tua kepada anak yaitu dengan mencubit, tidak memberi uang jajan, mengambil hp, dan memukul anak dengan kayu.

\section{Simpulan}

Berdasarkan hasil penelitian dan pembahasan, dapat disimpulkan bahwa bentuk akhlak anak dalam keluarga single parent yaitu delapan permasalahan tersebut dikelompokkan kepada dua aspek yaitu 1) tidak patuh terhadap orang tua, 2) permasalahan kepribadian seperti, i) berjudi, ii) berkelahi, iii) mencuri, iv) bergaul bebas, v) terpengaruh game online. vi) cenderung berbohong, vii) pacaran. Faktor penyebab anak melakukan hal demikian adalah kurangnya pemahaman orang tua dalam mendidik anak, kurangnya perhatian dari orang tua, dan pengaruh di lingkungan sekitar. Untuk mengatasi permasalahan di atas ada beberapa usaha orang tua mendidik akhlak anak pada keluarga single parent yaitu dengan nasehat baik itu langsung ataupun kiasan, keteladanan dari orang tua, dan hukuman seperti tidak memberi uang jajan, mengambil hp, memukul anak dengan kayu. Jika orang tua secara terus menerus menghukum anak dengan kayu maka akan berdampak kepada psikologis anak. Oleh karena itu diharapkan kepada orang tua agar memberikan hukuman itu dengan cara yang baik, dan orang tua juga harus memberikan perhatian yang banyak kepada anak, sehingga anak tidak menyimpang.

\section{Referensi}

Abdulroziq, R. (2019). Peran Orang Tua Mendidik Akhlak Anak dalam Membentuk Keluarga Harmonis di Dusun Malasan Kecamatan Durenan Kabupaten Trenggalek. IAIN Tulungagung.

Ahmadi, R. (2014). Pengantar Pendidikan Asas dan Filsafat Pendidikan. Ar-Ruzz Media.

Annis, I. (1972). Al-Mu'jam Al-Wasith. Dar al-Marif.

Astuti, W. A. (2020). Peranan Orangtua Tunggal dalam Pendidikan Akhlak Anak di Desa Pempen Kecamatan Gunung Pelindung. Institut Agama Islam Negeri Metro.

Darajat, Z. (2006). Membina Nilai-nilai Moral di Indonesia. Bulan bintang. 
Lastri Fatli Ashari dan Fuady Anwar: Usaha Ibu Single Parent dalam Mendidik Akhlak...

Darsono, P. (2010). Filsafat Ilmu Pendidikan. Nusantara Consulting.

Hidayat, N. (2017). Konsep Pendidikan Akhlak bagi Peserta Didik Menurut Pemikiran Prof.Dr.Hamka. Universitas Islam Negeri Raden Intan Lampung.

Juwita, D. R. (2018). Pendidikan Akhlak Anak Usia Dini di Era Milenial. At-Tajdid: Jurnal Ilmu Tarbiyah, 7(2), 282-314.

M. Yatim Abdullah. (2007). Studi Akhlak dalam Perspektif Al-Qur'an. Amzah.

Mustofa, A. (1997). Akhlak Tasawuf. Pustaka setia.

Patton, M. Q. (1991). How to Use Qualitative Methods in Evaluation. SAGE Publication.

Poerbakawatja, S. (1976). Ensiklopedi Pendidikan. Gunung Agung.

Saifuddin, A. (2016). Metode Penelitian. Yogyakarta: Arruz Media.

Setiawan, E. (2017). Konsep Pendidikan Akhlak Anak Perspektif Imam Al Ghazali. Jurnal Kependidikan, 5(1), 43-54.

Sholeh, F. (2020). Peran Orangtua dalam Mendidik Akhlak Anak di Desa Sri Basuki Kecamatan Batanghari Kabupaten Lampung Timur. Institut Agama Islam Negeri Metro.

Srinuryanti, I. (2019). Peran Ibu sebagai Orang Tua Tua Tunggal dalam Mendidik Akhlak anak. Institut Agama Islam Negeri Salatiga.

Sutinah. (2014). Metode Pendidikan Keluarga dalam Perspektif Islam. Konsultasi Dan Pendidikan Islam, 8 (2).

Syamsuddin, S. (2013). Perkawinan di Bawah Umur di Kecamatan Marioriwawo Kabupaten Soppeng Ditinjau dari Hukum Perkawinan. Universitas Islam Negeri Alauddin Makassar.

Ya'qub, H. (1993). Etika Islam. Diponegoro.

Zaman, B. (2018). Pendidikan Akhlak pada Anak Jalanan di Surakarta. Jurnal Inspirasi, 2(2).

Zamroni, A. (2017). Strategi Pendidikan Akhlak Pada Anak. Sawwa: Jurnal Studi Gender, 12(2). 